\title{
MÚSICOS NEGROS NO BRASIL COLONIAL: TRAJETÓRIAS INDIVIDUAIS E ASCENSÃO SOCIAL (SEGUNDA METADE DO SÉCULO XVIII E INÍCIO DO XIX)
}

\author{
Fernando Prestes de Souza (ferhist@yahoo.com.br) \\ Priscila de Lima (cila_lima@yahoo.com.br)
}

RESUMO: O presente artigo tem como objetivo geral averiguar as estratégias e possibilidades mobilizadas por homens de cor livres a fim de ascenderem socialmente, conforme os padrões de antigo regime, tendo como esteio o ofício e a arte musical. Para tanto, empreendeu-se análise de alguns fragmentos relativos ao campo musical composto por esses sujeitos no Brasil colonial, num período compreendido entre a segunda metade do século XVIII e as duas primeiras décadas do XIX. Ao mesmo tempo, procedeu-se a uma investigação comparativa entre as atuações de músicos das capitanias de Minas Gerais e São Paulo, justamente por constituírem espaços bem distintos no que diz respeito ao enquadramento social desses homens.

PALAVRAS-CHAVE: músicos de cor; Minas Gerais; São Paulo; séculos XVIII e XIX; ascensão social.

Com a chegada da corte portuguesa no Rio de Janeiro, em 1808, teve início um ímpeto modernizante, caracterizado pela implantação mais intensa dos signos da civilidade européia no Brasil. Nesse processo, o campo musical foi um dos alvos privilegiados pelas mudanças, que se materializaram através da criação da Casa da Ópera e da Capela Real, ambas destinadas a execução de música erudita, sendo aquela reservada às profanas e esta às sacras. Os dois espaços eram reconhecidos por neles se apresentarem obras de altíssima qualidade, à semelhança do que ocorria em Portugal. Assim, a Capela Real da nova sede do império lusitano foi instituída nos moldes da Capela lisboeta, famosa em toda a Europa por reproduzir à altura os 
grandes mestres italianos da época. ${ }^{1}$ Por meio destes dois espaços, aquilo que se considerava a tradição do bom gosto musical português foi mantida na América, atendendo-se, assim, às exigências de uma corte.

De fato, muitos foram os viajantes europeus que deixaram registradas suas impressões sobre a arte da música na nova corte de D. João VI. Um deles foi o cientista francês Louis Claude Desaulces Freycinet (1779-1842), que esteve no Rio de Janeiro entre 1817 e 1818, segundo o qual a música executada na Capela Real era admirável e "constituída quase que inteiramente de artistas negros, e cuja execução não deixa nada a desejar". ${ }^{2}$ Desta passagem chamamos a atenção para o fato de que os músicos que compunham a Real Capela eram majoritariamente negros. Nesse momento em especial, a instalação da corte portuguesa no Rio de Janeiro deveras possibilitou maiores oportunidades para esses músicos, que, carregando o estigma da cor, adentravam no mundo de relações com a nobreza. O padre José Maurício Nunes Garcia (1767-1830), homem mulato, foi o expoente máximo dessa relação de músicos de cor com a corte e o conseqüente reconhecimento de seus serviços. Era compositor, regente e organista. ${ }^{3}$ Sua ascensão pública ganhou notoriedade em 1798, quando foi designado mestre-de-capela da Sé do Rio de Janeiro. Na ocasião das cerimônias de boas-vindas da família real, em 1808, D. João VI tomou conhecimento do talento surpreendente e cativante de Nunes Garcia, e a partir desse primeiro contato o músico passou a compor obras de grande prestígio e refinamento, como a Missa de Nossa Senhora da Conceição para 8 de dezembro de 1810,

${ }^{1}$ CARDOSO, Lino de Almeida. O som e o soberano: uma história da depressão musical carioca pós-Abdicação (1831-1843) e de seus antecedentes. Tese (doutorado em História) - Faculdade de Filosofia, Letras e Ciências Humanas da Universidade de São Paulo, 2006. p. 98.

${ }^{2}$ Apud. CARDOSO, Lino Almeida. O som e o soberano..., p. 101.

${ }^{3}$ CARDOSO, Lino Almeida. Idem, p. 92; BERNARDES, Ricardo. José Maurício Nunes Garcia e a Real Capela de D. João VI no Rio de Janeiro. Revista Textos do Brasil, n. 12, s./d. p. 3. 
já à frente da Capela Real. No entanto, a historiografia sugere que a vinda de muitos músicos portugueses para o Rio de Janeiro teria causado a perda de hegemonia do padre Garcia como mestre-decapela da Sé, principalmente devido à concorrência do compositor e maestro Marcos Antonio da Fonseca Portugal (1762-1830). Seja como for, de acordo com Cardoso, essas afirmações não levam em conta as evidências concretas sobre a real função e peso participativo de Marcos Portugal no cenário musical da corte, que seria limitado. ${ }^{4}$

O caso do mulato Nunes Garcia constitui uma situação exemplar e notória justamente porque ocorreu em meio à exuberância da corte portuguesa, num contato direto deste sujeito com o centro de poder político, econômico e cultural lusitano. Contudo, podemos encontrar vestígios de outros homens de cor que exerceram o ofício e a arte da música sacra e erudita em outros espaços do Brasil, num período anterior ao da chegada da corte. Ao longo do século XVIII, por exemplo, teria florescido o que Francisco Lange chama de "escola de compositores da capitania geral das Minas Gerais", composta em sua maioria por homens de cor, "mulatos excepcionalmente experimentados na arte da música”. ${ }^{5}$ No que toca as outras capitanias, os vestígios destes indivíduos encontram-se mais fragmentados, condicionando o trabalho dos pesquisadores a análises muito pontuais, o que não chega a impedir a realização de estudos que contemplem estas localidades. A gênese deste artigo partiu da constatação dessas lacunas na história musical do Brasil colônia, principalmente respeitante aos músicos mulatos. Ao mesmo tempo, a historiografia pouco analisou a atuação social e os anseios destes homens livres de cor. Assim, busca-se aqui, através do exame de fontes primárias e material bibliográfico, apontar alguns traços gerais concernentes às estratégias e possibilidades dos músicos de cor da América portuguesa ascenderem socialmente, para, num segundo

\footnotetext{
${ }^{4}$ CARDOSO, Lino Almeida. Idem, p. 103-106.

${ }^{5}$ LANGE, Francisco Curt. A música barroca. In: HOLANDA, Sérgio Buarque de (Org.). História geral da civilização brasileira, $2^{\mathrm{a}}$ ed., t. I, v. II, livro III, São Paulo: Difusão européia do Livro, 1968a. p. 2.
} 
momento, comparar fragmentos da atuação destes sujeitos em dois espaços cuja vida musical foi bastante distinta: a capitania de Minas Gerais, com seu esplendor musical, e a de São Paulo, bem mais modesta, entre a segunda metade do século XVIII e as duas primeiras décadas do século XIX.

\section{A música colonial do Brasil como objeto da história}

Historiadores dedicados ao estudo das expressões culturais de africanos e seus descendentes nas Américas destacam veementemente a rica musicalidade inerente às manifestações públicas destes sujeitos. Na América portuguesa, a música surgia atrelada a danças e rituais religiosos, além de ser componente fundamental das capoeiras e do trabalho cotidiano dos negros. Como práticas coletivas, muitos historiadores analisam-nas não como atos "desinteressados" da parte dos homens de cor livres ou escravos, mas como constituintes da disputa cultural e política que envolvia sobretudo europeus e brancos em geral, de um lado, e africanos e crioulos com as máculas do cativeiro, de outro. O toque dos instrumentos e os ritmos daí decorrentes, configurados na América portuguesa, remetiam genericamente a um passado africano. A musicalidade negra pode ser vista, em suma, como uma arma essencial na resistência cultural. ${ }^{6}$

Entretanto, uma outra face da expressão cultural de homens de cor por meio da música pouco ou nada aludia a africanismos, sequer implicava resistência. Ao contrário, milhares de pardos, pretos e mulatos dedicaram-se intensamente ao estudo e ensino, produção e

\footnotetext{
${ }^{6}$ MATTOS, Regiane Augusto de. De cassange, mina, benguela a gentio da Guiné. Grupos étnicos e formação de identidades africanas na cidade de São Paulo (18001850). Dissertação (mestrado em história) - Faculdade de Filosofia, Letras e Ciências Humanas da Universidade de São Paulo, 2006. p. 137-185; SCHWARTZ, Stuart. Cantos e quilombos numa conspiração de escravos haussás - Bahia, 1814. In: REIS, João José; GOMES, Flávio dos Santos (Orgs.). Liberdade por um fio. História dos quilombos no Brasil. São Paulo: Companhia das Letras, 1998. p. 382383.
} 
reprodução de música erudita no Brasil colonial. Este aspecto chamou a atenção dos historiadores Herbert Klein e Russell-Wood, já na década de 1960, os quais incitaram outros pesquisadores a aprofundarem as análises referentes às atividades musicais daqueles sujeitos. $^{7}$ Visavam uma melhor compreensão da camada social intermediária entre senhores brancos e escravos, composta por homens livres de cor.

Russell-Wood e Klein, em verdade, amplificaram a voz do musicólogo alemão Francisco Curt Lange, que desde a década de 1940 trabalhou na coleta e interpretação de fontes relacionadas à vida musical erudita do Brasil colonial. A ênfase de Lange na capitania de Minas Gerais resultou na divulgação da idéia de que a música ali praticada ao longo do século XVIII assemelhava-se em qualidade à européia. Mais ainda, "descobrira” que os virtuosos musicistas eram em sua maioria pardos e mulatos. Não por acaso concentrou seus estudos na obra de um homem de cor, José Joaquim Emérico Lobo de Mesquita (1746-1805), o qual foi por Lange considerado "o maior de todos os compositores mineiros". 8

A partir da década de 1960 a musicologia brasileira ganha em número e espaço, pois, conforme Castagna, multiplicaram-se os "herdeiros" de Francisco Lange por esta época, os quais buscaram apreender a vida musical erudita de outras capitanias e,

${ }^{7}$ KLEIN, Herbert S. The colored freemen in brazilian slavery society. Journal of Social History, v. 3, n. 1, 1969. p. 48-49; RUSSELL-WOOD, A. J. R. Escravos e libertos no Brasil colonial. Trad. Maria Beatriz de Medina. Rio de Janeiro: Civilização Brasileira, 2005. p. 150-152.

8 LANGE, Francisco Curt. A música barroca..., p. 140. Apesar das grandes contribuições de Francisco Curt Lange à pesquisa sobre a música erudita na América portuguesa, Castagna critica rigorosamente pelo menos três características do musicólogo em questão: sua ênfase nas "descobertas", a preocupação em estabelecer julgamentos de valor em relação às "escolas” e composições individuais, e, por fim, a postura de Lange em dificultar o acesso a seu vasto acervo documental colhido principalmente no Rio de Janeiro e Minas Gerais CASTAGNA, Paulo. Avanços e perspectivas na musicologia histórica brasileira. In: Revista do Conservatório de Música da UFPel. Pelotas, n. 1, 2008. 
conseqüentemente, “descobrir" outros compositores e intérpretes. Não obstante as inúmeras diferenças entre os pesquisadores em questão, devem ser mencionados ao menos dois traços em comum entre eles: primeiramente, o empenho por "comprovar a existência de uma prática musical 'erudita' no Brasil anterior ao já mencionado padre José Maurício Nunes Garcia”; em segundo lugar, destaque-se o empreendimento arqueológico, como costumavam denominar, de busca por indícios, vestígios e resquícios sobre a música praticada nas capitanias às quais debruçaram-se. Mais especificamente, Castagna indicou criticamente a tendência entre os musicólogos das décadas de 1960 a 1980 a elegerem cada qual um personagem para suas pesquisas, de tal modo que pudessem exercer uma espécie de monopólio investigativo, ou um "exclusivismo autoral". ${ }^{9}$ A exemplo da predileção de Lange à figura de Lobo de Mesquita, Cleofe Person de Mattos concedeu especial atenção às composições de José Maurício Nunes Garcia (1767-1830) no Rio de Janeiro, Régis Duprat centrou-se na capitania de São Paulo e na música de André da Silva Gomes (1752-1844) e Jaime Diniz na produção de Luís Álvares Pinto (c.1719 - c.1789), em Pernambuco, e Damião Barbosa Araújo (17781856), da Bahia. ${ }^{10}$ Com exceção do músico português André da Silva Gomes, os demais eram homens de cor e figuram entre os principais nomes da música erudita da América portuguesa.

É bastante comum nos trabalhos de musicologia um certo tom de "desabafo" por parte de seus autores, particularmente relacionado às fontes de pesquisa. Se, de um lado, sugere-se que muito do que se produziu e se praticou na América portuguesa está perdido para sempre, uma vez que partituras e demais vestígios sofreram diversos tipos de deterioração ao longo de mais de dois séculos, de outro há as dificuldades atuais de acesso aos documentos, como a falta de catalogação nos arquivos e a postura de entes privados em obstar a

\footnotetext{
${ }^{9}$ CASTAGNA, Paulo. Avanços e perspectivas na musicologia histórica brasileira... ${ }^{10}$ CASTAGNA, Paulo. Idem, p. 41.
} 
consulta. $^{11}$ De certa forma, esse quadro dificultoso reflete no conhecimento acerca da vida musical do Brasil colonial, ao que se soma o restrito - mas extremamente necessário - diálogo entre musicólogos e historiadores. A escassez de fontes e o precário diálogo interdisciplinar resultam, pois, numa imagem geral segundo a qual aqui existiam ilhas de música erudita. Fala-se do esplendor mineiro e de alguma expressão erudita em Pernambuco e na Bahia durante o século XVIII, ao passo que a segunda sede da colônia e posterior capital do império português, o Rio de Janeiro, obtém relevo nas pesquisas tão somente em relação ao século XIX. A situação concernente à capitania de São Paulo parece ainda mais agravante: indicou Régis Duprat que "o conhecimento da modesta e inexpressiva vida musical da vila de São Paulo no século dezoito encontra, pelo menos até o último quartel, um obstáculo enorme na precariedade de fontes, talvez significativa da própria precariedade da atividade musical". ${ }^{12}$ Ademais, apesar dos esforços acadêmicos implementados a partir da década de $1990^{13}$, permanece hegemônico o caráter biográfico dos estudos, ou seja, à exceção de alguns nomes para cada uma das capitanias acima referidas, pouco se sabe sobre a multidão de anônimos que exerciam sua arte nestes diversos espaços do Brasil, e tampouco as relações e particularidades das diversas configurações sociais. A constatação feita por Duprat, em 1975, de acordo com a qual "não foram propostas hipóteses para os grandes problemas da organização do trabalho musical da época” parece ainda ser válida no que diz respeito às questões levantadas por Herbert Klein, o qual

${ }^{11}$ CASTAGNA, Paulo. Idem; DUPRAT, Régis. Música na Matriz da Sé de São Paulo colonial. Anuario Interamericano de Investigacion Musical, v. 11, 1975. p. 810; LANGE, Francisco Curt. Os irmãos músicos da Irmandade de São José dos Homens Pardos, de Vila Rica. Anuario Interamericano de Investigacion Musical, v. 4, $1968 \mathrm{~b}$.

${ }^{12}$ DUPRAT, Régis. Música na Matriz da Sé..., p. 9.

13 CASTAGNA, Paulo. Avanços e perspectivas na musicologia histórica brasileira... 
indicou a atuação musical de homens de cor como um importante aspecto de suas estratégias visando mobilidade social. ${ }^{14}$

Pode-se afirmar que até a chegada da família real ao Rio de Janeiro e a decorrente fundação da Capela Real - onde se executava música de corte - era nas igrejas que se concentrava grande parte da música erudita praticada na América portuguesa. ${ }^{15}$ "A principal forma de atividade profissional do músico”, então, "era a música religiosa, na igreja ou fora dela, litúrgica ou não" ${ }^{16}$ Entretanto, além da música sacra que atendia, dentre outras, as demandas das igrejas matrizes, irmandades religiosas leigas e das câmaras de todas as vilas do Brasil, havia a música instrumental erudita e as representações cênicomusicais, estas últimas executadas nas Casas de Ópera e mantidas por particulares. ${ }^{17}$ Mesmo nestas modalidades de música profana os cantores e instrumentistas que as executavam prestavam seus serviços fundamentalmente nas igrejas.

A atividade em questão se inscreve, sem dúvida, no interior do padrão de produção típico de Antigo Regime, associado à arte de artesão. Nele, a obra é produzida sob encomenda e, portanto, permanece subordinada ao gosto do patrono. A relação entre produtor e consumidor é invariavelmente caracterizada pela desigualdade de status social entre as duas partes, sendo a posição inferior associada ao produtor. Nesse particular, as condições de produção diferem muito da arte de artista. Nesta, resultante de um processo responsável pela mudança da posição social dos artistas e do estilo e caráter de suas obras, o músico apresentava-se como "autônomo" e, destinando

\footnotetext{
${ }^{14}$ DUPRAT, Régis. Idem, p. 10; KLEIN, Herbert S. The colored freemen...; p. 20. ${ }^{15}$ MONTEIRO, Maurício. Música na corte do Brasil: entre Apolo e Dionísio (18081821). Textos do Brasil, n. 12, s./d. p. 35-36.

${ }^{16}$ ORBINO, N. P.; DUPRAT, R. O estanco da música no Brasil colonial. Anuario Interamericano de Investigacion Musical, v. 4, 1968. p. 98.

${ }^{17}$ LANGE, Francisco Curt. A música barroca..., p. 135-136.
} 
suas obras para um público anônimo, suplantou o padrão de gosto do patrono e passou a ser formador de gostos e estilos.

Evidentemente, “o mestre-de-capela, compositor e regente, é a peça mestra deste sistema, pois trata e contrata serviços, recebe e paga executantes que elege conforme suas conveniências artísticas e pecuniárias". ${ }^{19}$ Havia, no tocante às remunerações, diferenças consideráveis entre a situação de um mestre-de-capela das Sés e a de um mestre vinculado a uma paróquia matriz: se àquele era concedida, e tão somente pelos bispos, uma provisão com a obrigação de atender ao serviço musical da Sé em que atuava com seus músicos, sustentar escola pública e com direito a salário pago pela Fazenda Real, a um mestre de matriz, provido por padres, não havia salário régio. Este, mais próximo da realidade vivida pela maioria dos músicos no contexto colonial, se mantinha "através de serviços eventuais das irmandades, das câmaras municipais - nas festas reais - e dos festeiros, nas festas locais e outras, como ofícios fúnebres”. Além disso, nas cidades e vilas mais pobres, com a necessidade de complemento financeiro, recorriam ao desempenho de outras profissões. ${ }^{20}$

Duprat e Orbino organizaram conceitualmente um sistema complexo, ilegal mas vigente, de financiamento dos espetáculos musicais, o qual conectava bispos e autoridades religiosas locais, mestres-de-capela vinculados diretamente às sés, os mestres-decapela subordinados aos mestres das sés, e, por fim, os contratantes dos serviços. Em teoria, o bispo, cabido ou vigário capitular concediam pensão anual ou por festa pelo exercício do oficio de mestre-de-capela, com fins a garantirem a função do mestrado. Por sua vez, “o mestre da Sé ou Matriz concede o ‘beneplácito’ a outros mestres, recebendo deles para poderem 'levantar o compasso' nas igrejas de sua jurisdição". Porém, funcionava na prática o "estanco

${ }^{18}$ ELIAS, Norbert. Mozart, sociologia de um gênio. Rio de Janeiro: Jorge Zahar Ed., 1995, p. 45-47.

${ }^{19}$ ORBINO, N. P.; DUPRAT, R. O estanco da música no Brasil colonial..., p. 98.

${ }^{20}$ ORBINO, N. P.; DUPRAT, R. Idem, p. 99. 
musical”, que consistia na cobrança feita pelos bispos ao mestre-decapela da Sé pela concessão do beneplácito, por ano ou por festa, enquanto este exigia valores mais altos dos demais mestres-de-capela para conceder-lhes licenças para atuarem nas festas. Ou seja, se comumente os mestres-de-capela das Sés pagavam altos valores em suas provisões, de outra parte resguardavam para si o monopólio da contratação de músicos, não sem contestações, é bem verdade. ${ }^{21}$ Todavia, não se quer afirmar com isso que os critérios para ocupação destes cargos de relevo reduziam-se à compra dos mesmos. As qualidades técnicas e estilísticas, a conduta individual, o status social e as ligações pessoais com as altas autoridades civis e eclesiásticas sem dúvida eram critérios considerados na avaliação dos músicos aspirantes e concorrentes ao posto em questão.

Tratando-se dos privilégios e vantagens à disposição dos mestres-de-capela, como se pôde observar, Régis Duprat e Nise Orbino, bem como outros musicólogos, chamam a atenção basicamente para o aspecto econômico. Interessados em outras questões atinentes à prática musical, como as condições institucionais e a caracterização técnica e estilística dos músicos, predominantemente pardos e mulatos, tais estudiosos freqüentemente perdem de vista os bens simbólicos em jogo nestas relações de poder. Refletindo sobre os objetivos de indivíduos e grupos humanos imersos em relações nas quais há diferencial de poder, Norbert Elias sugeriu que o nível de poder dos vários agentes atuantes tem íntima conexão com os objetivos em disputa. Isto é, quanto mais indivíduos e grupos encontram-se em inferioridade de poder em relação a outros sujeitos e grupamentos, maior é a sua ênfase nos bens econômicos. Contudo, à medida que os grupos se igualam, inclusive economicamente, manifesta-se maior tendência para que a luta tenha

${ }^{21}$ ORBINO, N. P.; DUPRAT, R. O estanco da música no Brasil colonial..., p. 100101. 
como meta a satisfação de outras aspirações humanas. ${ }^{22}$ Elias alerta, em suma, para a coexistência, nas disputas de poder entre grupos e indivíduos, da busca por bens materiais e simbólicos. Cabe destacar que na formação social de Antigo Regime o capital simbólico desempenhava papel fundamental em sua estruturação. Convém, deste modo, compreender os diversos recursos e aspirações destes músicos negros naquela sociedade, a qual se orientava por certos princípios e ideais, como honra, pureza de sangue, adesão a determinados padrões de civilidade e uma concepção de justiça específica. ${ }^{23}$

\section{Trajetórias individuais e possibilidades de ascensão social}

$\mathrm{O}$ enquadramento de homens e mulheres de cor em corporações de ofício, irmandades religiosas e corpos militares tem sido visto pelos historiadores como etapa estratégica e fundamental do processo de mobilidade social ascendente ao qual aspiravam, na sociedade colonial, estes sujeitos de alguma forma atados à escravidão. ${ }^{24}$ Tais corporações pautavam-se na divisão entre brancos e negros e, por conseguinte, vincular-se a uma instituição própria a pessoas de cor implicava a assimilação do estigma. Entretanto, emulados pelas possibilidades de ocuparem postos de destaque nas hierarquias, mediante os quais exerciam autoridade sobre seus pares, os indivíduos de cor aderiam a tais corporações. Tratava-se, nestas circunstâncias, de processo de ascensão social no interior do próprio grupo ou "classe" de pessoas. Por outro lado, havia outro nível de

${ }^{22}$ ELIAS, Norbert. Introdução. Ensaio teórico sobre as relações estabelecidosoutsiders. ELIAS, Norbert; SCOTSON, John. Os estabelecidos e os outsiders. Trad. Vera Ribeiro. Rio de Janeiro: Jorge Zahar Editor, 2000. p. 33-34.

${ }^{23}$ HESPANHA, António Manuel. A mobilidade social na sociedade de Antigo Regime. Tempo, v. 11, n. 21, 2006.

${ }^{24}$ KLEIN, Herbert S. The colored freemen..., p. 4-5; RUSSELL-WOOD, A. J. R. Escravos e libertos..., p. 127-142; SILVA, Luiz Geraldo. Da festa à sedição: sociabilidades, etnia e controle social na América portuguesa (1776-1814). História: Questões \& Debates, Curitiba, n. 30, 1999. 
mobilidade social ascendente, o qual consistia na passagem de um estamento a outro. Sobre esta matéria, alguns historiadores têm procurado demonstrar estratégias de longo prazo levadas a efeito por sujeitos considerados negros na América portuguesa que tinham como objetivo o branqueamento social, ou seja, se possível a desvinculação total dos estigmas da escravidão. Geralmente tais projetos de vida passavam pelo enquadramento em corporações religiosas, militares e de ofício, mas também eram assentados sobremaneira na relação pessoal mantida com as elites econômicas e autoridades locais, sobretudo por meio de laços teoricamente estáveis, como o compadrio, matrimônio, etc. ${ }^{25} \mathrm{Em}$ decorrência, tratava-se não somente de uma trajetória individual, mas de um processo geracional, com avanços e percalços. Nele o indivíduo já herdava de seus pais e avós uma posição ascendente em relação a estes, ou a alcançava no decorrer de sua vida, e tendia buscar a ampliação dessas conquistas para seus herdeiros.

De acordo com o que se sugere aqui, associada a outros mecanismos, a atividade musical funcionava como uma via de mobilidade aos homens de cor. E isso era percebido pelas elites lusobrasileiras. José João Teixeira Coelho, por exemplo, em sua Instrução para o governo da capitania de Minas Gerais, de 1780, criticou severamente a atitude vaidosa dos povos em desprezar o trabalho com vistas na obtenção do status de fidalgos. Conforme Teixeira Coelho não havia "na capitania de Minas um homem branco, nem uma mulher branca, que queiram servir; porque se persuadem que lhes fica mal um emprego que eles entendem que só compete aos escravos". Seu ponto de vista não deixa dúvidas quanto à busca dos homens livres de cor daquela capitania em se destacarem da camada de escravos e aproximarem-se do grupo de brancos: "esta presunção e ociosidade dos brancos se tem transferido aos mulatos e negras,

${ }^{25}$ FERREIRA, Roberto Guedes. Sociedade escravista e mudança de cor. Porto Feliz, São Paulo, século XIX. In: FRAGOSO, João [et al.] (Org.). Nas rotas do império: eixos mercantis, tráfico e relações sociais no mundo português. Vitória/Lisboa: EDUFES/IICTP, v.1, 2006. 
porque uma vez que são forros não querem trabalhar nem servir”. Finalmente, toca no ponto central da discussão aqui considerada, indicando que "aqueles mulatos que se não fazem absolutamente ociosos se empregam no exercício de músicos, os quais são tantos na capitania de Minas que certamente excedem o número dos que há em todo o reino" ${ }^{26} \mathrm{O}$ autor da célebre Instrução, portanto, destaca que o "aluvião de músicos” que compunham o faustuoso e singular movimento de música barroca mineira para os padrões da América portuguesa não eram "absolutamente ociosos", mas deixa entender que tampouco a arte da música era ali considerada um ofício mecânico e de certa forma desonroso.

Note-se que a sociedade portuguesa de Antigo Regime foi caracterizada pela atribuição de máculas a certos grupos sociais com base em critérios de "pureza de sangue”. Nesta lógica hierárquica, tanto aos executores de ofícios mecânicos como aos judeus, mouros, indígenas e negros e seus descendentes eram vedadas a entrada em cargos públicos e o recebimento de honras e mercês. ${ }^{27}$ No que toca aos ofícios mecânicos, a historiografia tem chamado atenção para o fato de que as exclusões tinham um caráter aristocrático, pois buscavam delinear as diferenças entre nobres - que não trabalhavam com as mãos - e os "outros", que dependiam exclusivamente do trabalho manual para sobreviver. ${ }^{28} \mathrm{E}$, por operar no interior do padrão de produção da arte de artesão, no qual assim o produtor como o produto subordinavam-se à lógica da encomenda, ${ }^{29}$ o oficio da música poderia estar associado aos ofícios mecânicos. Entretanto, esta arte

${ }^{26}$ Cf. COELHO, João José Teixeira. Instrução para o governo da capitania de Minas Gerais, 1780. In: Revista do Arquivo Público Mineiro, VIII: 1-2 (jan./jun. 1903), p. 399-581.

${ }^{27}$ CARNEIRO, Maria Tucci. Preconceito racial: Portugal e Brasil-colônia. São Paulo: Brasiliense, 1988, p. 47; OLIVAL, Fernanda. Rigor e interesses: Os estatutos de pureza de sangue em Portugal. Cadernos Sefardistas, n. 4, p. 151-182, 2004.

${ }^{28}$ VIANA, Larissa. O idioma da mestiçagem: As irmandades de pardos na América portuguesa. Campinas: Editora da Unicamp, 2007. p. 52.

${ }^{29}$ ELIAS, Norbert. Mozart, sociologia de um gênio. Rio de Janeiro: Jorge Zahar Ed., 1995, p. 45-47. 
deve ser ponderada de forma a se considerar a complexidade com que ela se inscrevia na sociedade de Antigo Regime. Ora, as artes dividam-se em dois ramos, a saber, as artes liberais e as artes mecânicas. As sete artes liberais eram gramática, retórica, lógica, aritmética, música, arquitetura e astrologia, ao passo que as mecânicas eram constituídas por agricultura, caça, guerra, todos os ofícios fabris, a cirurgia e as artes de tecer e navegar. ${ }^{30}$ Deste modo, mediante esta diferenciação entre as artes, tem-se que a dedicação às artes liberais não implicava o estabelecimento de mácula aos indivíduos, "pois tais artes não dão nem tiram a nobreza". ${ }^{31}$ Note-se, porém, que a existência de pessoas que se ocupavam tanto da produção de músicas quanto da fabricação de instrumentos musicais gerava uma outra situação: o artista liberal tornava-se, ao mesmo tempo, oficial mecânico - e este último aspecto tendia a prevalecer na caracterização social do individuo. Orientado por essa lógica, a de marcar a cisão entre a arte da música e o oficio artesanal, o compromisso da irmandade de Santa Cecília (Rio de Janeiro, 1797), composta exclusivamente por músicos, determinava que "não serão admitidos na Irmandade senão os professores que tiverem verdadeira inteligência da música (...) excluindo toda a [pessoa] que exercitar ofício mecânico. Poderão porém ser admitidos todos os que exercitarem ofícios nobres pela utilidade que destes pode resultar a confraria”. ${ }^{32}$

Por sua vez, os aspirantes a um posto de mestre-de-capela compreendiam que exercendo a referida função teriam como

30 BLUTEAU, Raphael. Vocabulario portuguez \& latino: aulico, anatomico, architectonico ... Coimbra: Collegio das Artes da Companhia de Jesus, 1712 - 1728. 8 v. Disponível em: http://www.brasiliana.usp.br/ e http://www.ieb.usp.br/. Verbete “arte", v. 1, p. 573.

${ }^{31}$ HESPANHA, Antonio Manuel. Às vésperas do Leviathan: instituições e poder político, Portugal - séc. XVII. Coimbra, Almedina, 1994, p. 347.

${ }^{32}$ Cf. "Registro de compromisso da Irmandade da gloriosa virgem e mártir Santa Cecília para aqueles desejosos de ingressar como membro da irmandade”. Rio de Janeiro, 8 de outubro de 1787. Arquivo Nacional (Brasil). Registro Geral de Ordens Régias, códice 64, vol. 20. 
subordinados todos os demais músicos e alunos da região, os quais poderiam ser predominantemente mulatos, como em Minas Gerais, mas poderiam igualmente ser brancos. Em outros termos, trata-se de uma posição de poder e prestígio ocupada mediante um processo de mobilidade ocupacional. O musicólogo Francisco Lange argumentou que as irmandades religiosas de Ouro Preto dedicavam uma grande porcentagem da verba destinada às festas ao serviço da música. Inclua-se aí o pagamento a escravos e transportadores, os quais conduziam os músicos, vestidos com trajes finos e luxuosos, e seus instrumentos aos locais de atuação. ${ }^{33}$ Ora, percebe-se grande preocupação dos musicistas, e não somente por parte dos mestres-decapela, em apresentar-se com evidência e realce perante a sociedade. E isso não por acaso, já que "as cerimônias públicas que exigiam música eram as mais importantes e nelas se fazia presente a elite da hierarquia social. Esses músicos, portanto, tinham que adequar suas roupas, perucas, sapatos e postura à solenidade dessas representações, pois delas participavam".

A ênfase nos bens econômicos advindos da atividade musical levou alguns estudiosos a interpretarem outras facetas da vida destes artistas - em geral extremamente conexas - como complementares em termos financeiros. Assim, nas circunstâncias em que o mercado de trabalho passava por recessão, músicos exerciam outros ofícios e paulatinamente deixavam de lado sua arte. $\mathrm{O}$ ingresso de músicos de cor em corpos militares e irmandades religiosas, espaços onde cotidianamente prestavam seus serviços, foi recorrentemente visto e justificado através desta necessidade de trabalho e renda. Entretanto, não se pode deixar de observar que nas sociedades de Antigo Regime não estavam em jogo apenas recursos econômicos, mas igualmente outras formas de bens, situados no campo simbólico. Estes poderiam desencadear processos de ascensão social que não estavam

\footnotetext{
${ }^{33}$ LANGE, Francisco Curt. Os irmãos músicos da Irmandade..., p. 123-124.

${ }^{34}$ LEONI, Aldo Luiz. Os que vivem da arte da música - Vila Rica, século XVIII. Dissertação (mestrado em História) - Instituto de Filosofia e Ciências Humanas da UNICAMP, 2007. p. 10.
} 
relacionados predominantemente ao acúmulo de pecúlios. Os oficiais militares pardos, por exemplo, gozavam de certos privilégios assegurados por suas cartas-patentes, como o foro militar ou a permissão para utilizarem adereços e signos de prestígio em seus uniformes, ao passo que aos sujeitos vinculados a irmandades era permitido a realização de procissões e festas anuais, nas quais externavam tanto as hierarquias intra-irmandades como em relação às outras corporações religiosas de negros. Deve-se enfatizar que os músicos de cor habitualmente se enquadravam em tais instituições, ocupando nelas os mais altos postos ${ }^{35}$, ao que vinha a somar toda a pompa envolta nas apresentações musicais.

As demonstrações públicas de adequação aos rígidos padrões de comportamento e civilidade, próprios a sociedade de Antigo Regime, era algo que estes homens de cor buscavam utilizar a seu favor no contato com as principais autoridades portuguesas. Em primeiro lugar, vale lembrar que a vasta maioria da população da América portuguesa era analfabeta durante o século XVIII e início do XIX. ${ }^{36}$ Os músicos de cor pareciam realmente estar em posição de relativo destaque na sociedade colonial quanto ao domínio da leitura e escrita. Salientando a tamanha circulação de informações que conectava músicos de cor das Minas Gerais e Rio de Janeiro às vanguardas européias no campo da música erudita, durante o século XVIII, Francisco Lange afirmou que "o analfabetismo era inexistente entre os músicos. Sua caligrafia era excelente, prolixa e fluida,

\footnotetext{
${ }^{35}$ LANGE, Francisco Curt. Os irmãos músicos da Irmandade..., p. 125; LANGE, Francisco Curt. Algumas novidades em torno a atividade musical erudita no período colonial de Minas Gerais. Latin American Music Review, v. 4, n. 2, Autumn Winter, 1983. p. 250; LEONI, Aldo Luiz. Os que vivem da arte da música... p. 135166.

${ }^{36}$ VILLALTA, Luiz Carlos. O que se fala e o que se lê: língua, instrução e leitura. In: SOUZA, Laura de Mello e (org). História da Vida Privada no Brasil: Cotidiano e vida privada na América portuguesa. São Paulo: Companhia das Letras, v. 1, 1997, p. 354.
} 
conseqüência de constantes cópias de música e do texto em latim”. ${ }^{37}$ Deste modo, não é de se estranhar que a descrição do músico Luiz Álvares Pinto (c.1719 - c.1789), feita pelo musicista a ele contemporâneo José Mazza em algum momento da segunda metade do século XVIII, destaque antes seu alto grau de instrução nas letras, para depois tratar de sua habilidade e produção musical:

Luiz Álvares Pinto, natural de Pernambuco, homem pardo, excelente poeta português e latino, muito inteligente na língua francesa e italiana; acompanhava muito bem rabecão, viola, rabeca. Veio a Lisboa aprender contraponto com o célebre Henrique da Silva; tem composto infinitas obras com muito acerto, principalmente eclesiásticas; compôs ultimamente umas exéquias à morte do senhor rei D. José o I a quatro coros, e ainda em composições profanas tem escrito com muito acerto. ${ }^{38}$

O caso do músico Luis Álvares Pinto, que, segundo Paulo Castagna, foi o compositor nordestino mais conhecido do período colonial, foi realmente singular. Como se viu, parte de sua instrução musical deu-se em Portugal, onde permaneceu de 1740 até por volta de 1760. No reino estabeleceu um importante contato com Martinho de Melo e Castro, então ministro da Marinha e Ultramar, após tornarse professor de música de suas filhas. Retornou ao Recife e em 1761 já havia adquirido o cargo de mestre régio de instrução primária, ensinando música. Ao longo das décadas de 1760 e 1770 somaram-se outras funções como a de escrivão da irmandade de Nossa Senhora do Livramento e capitão de um dos terços auxiliares do Recife. ${ }^{39}$

Pensando especificamente nas relações que podem ser estabelecidas entre o exercício da música por mulatos e a conseqüente obtenção de certo status na América portuguesa, a trajetória de vida

${ }^{37}$ LANGE, Francisco Curt. Sobre las dificiles huellas de la musica antigua del Brasil: la "Missa abreviada" del Padre José Maurício Nunes Garcia. Anuario Interamericano de Investigacion Musical, v. 1, 1965; LANGE, Francisco Curt. Os irmãos músicos..., p. 138.

38 Cf. MAZZA, José. Dicionário biográfico de músicos portugueses. Lisboa: Editorial Império, 1945, p. 33.

39 CASTAGNA, Paulo. Avanços e perspectivas na musicologia histórica brasileira..., p. 12-13. 
do já mencionado padre e músico carioca José Maurício Nunes Garcia foi, provavelmente, a mais fabulosa. Este indivíduo, em petição de dez de junho de 1791 clamava a graça de ser "dispensado da cor”, para que assim pudesse habilitar-se no sacerdócio. Para isso alegava que recebera boa educação de seus pais, aplicando-se nos estudos da gramática, retórica, filosofia moral e na arte da música, além de que sempre vivera com regularidade nos seus costumes. Assim, o único impedimento para suas aspirações era a ascendência africana. Para contentamento do peticionário, o caso terminou com despacho favorável do provedor do bispado. ${ }^{40}$ A partir de 1798 exerceu a importantíssima função de mestre-de-capela da Sé do Rio de Janeiro, na capital do Estado do Brasil. ${ }^{41} \mathrm{O}$ auge da carreira de Nunes Garcia como músico se deu entre o período da chegada da corte portuguesa ao Rio de Janeiro até 1811, quando foi substituído pelo português Marcos Portugal na função de diretor e compositor da Real Capela. Entretanto, beneficiado pelas possibilidades de conquistar o status de nobreza via prestação de serviços e relações pessoais mantidas com o soberano, em 1809 o padre mulato foi agraciado por D. João VI com o Hábito da Ordem de Cristo. ${ }^{42}$

Os brilhantes caminhos percorridos tanto pelo pernambucano Luis Álvares Pinto quanto pelo carioca José Maurício Nunes Garcia seguramente não são representativos da carreira de todos os músicos livres de cor do Brasil, ao longo do setecentos e início do século XIX. Estes traços das trajetórias de músicos de cor, apresentados aqui um tanto quando aleatoriamente, eram possibilidades, não regras. Cabe, agora, investigar as estratégias e perspectivas destes musicistas por

${ }^{40}$ OLIVEIRA, A. J. M. Suplicando a "dispensa do defeito da cor": clero secular e estratégias de mobilidade social no Bispado do Rio de Janeiro - século XVIII. XIII Encontro de História da Anpuh-Rio, 2008, Seropédica. Anais do XIII Encontro de História da Anpuh-Rio. Rio de Janeiro: Anpuh-Rio, 2008. p. 1-2.

${ }^{41}$ BERNARDES, Ricardo. José Maurício Nunes Garcia e a Real Capela de D. João VI no Rio de Janeiro. Revista Textos do Brasil, n. 12, s./d. p. 42.

42 BERNARDES, Ricardo. Idem, p. 43; HESPANHA, António Manuel. A mobilidade social..., p. 135-143. 
um olhar mais aprofundado, dirigido a dois espaços significativamente distintos no campo da música erudita.

\section{Músicos pardos e mulatos nas capitanias de Minas Gerais e São Paulo}

A constituição das Minas Gerais deveu-se ao suntuoso afluxo de indivíduos que para lá partiram desde finais do século XVII em busca do enriquecimento proporcionado pela descoberta do ouro. Sabe-se que tal configuração social, derivada em boa medida da mineração e do grande contingente de escravos, teria propiciado a obtenção de pecúlios pelos cativos, que tiveram maiores condições de adquirirem a alforria. Essa maior mobilidade deu origem a uma sociedade dinamizada pela existência de um grande número de homens de cor livres, os quais se destacavam no exercício de ofícios mecânicos e artísticos. ${ }^{43}$

Os músicos por nós aqui tratados surgiram justamente desse grupo social intermediário, pois "foi produzido em Minas Gerais um processo sem precedentes na história da música, visto que cantores, compositores, instrumentistas e regentes foram em sua maioria homens híbridos, ou seja, pessoas de pele escura". ${ }^{44}$ Dessa forma, a inserção social destes indivíduos foi caracterizada por certo grau de complexidade, visto que não eram escravos, mas ao mesmo tempo conviviam com os entraves para alçarem os privilégios de homens brancos. Muitos vestígios sobre a atuação dos músicos encontram-se dispersos ou perdidos para sempre, e a documentação que revela alguns traços dessa experiência concentra-se essencialmente a partir da segunda metade do século XVIII. Isso pode ter relação, como

${ }^{43}$ KLEIN, Herbert S. Os homens livres de cor na sociedade escravista brasileira. Dados - Revista de Ciências Sociais, n. 17, 1978. p. 19-20; MARQUESE, Rafael de Bivar. A dinâmica da escravidão no Brasil: resistência, tráfico negreiro e alforrias, séculos XVII a XIX. Novos Estudos. São Paulo, n. 74, 2006. p. 9.

${ }^{44}$ LANGE, Francisco Curt. La música en Vila Rica: Minas Gerais século XVIII. Revista Musical Chilena, n.102, 1967. p. 12. 
observou o historiador Aldo Luiz Leoni, com mudanças ocorridas na estrutura de contratação dos serviços musicais, visto que, se durante a primeira metade do dito século eram monopolizados por mestres brancos, a partir da segunda metade passaram majoritariamente para o encargo de homens de cor. Os pardos livres que executavam as funções de regência e ao mesmo tempo a de compositores, sob a designação de mestres conduziam conjuntos musicais constituídos também por homens de cor não cativos. ${ }^{45} \mathrm{~A}$ existência de tais grupos certamente contribuiu para o aumento significativo desses contingentes como executores das atividades musicais da capitania.

Pode-se dizer que a área de atuação musical estava dividida em três esferas fundamentais: câmaras, irmandades e os regimentos militares. No entanto, eram os atos litúrgicos - contratados pelas câmaras e irmandades - que concediam os principais meios de sobrevivência para estes músicos. ${ }^{46}$ As festas públicas e anuais eram de responsabilidade das câmaras e constituíam-se de eventos como o Corpus Christi e as festas em homenagem ao santo protetor de cada vila. Outras solenidades davam-se de acordo com as novidades vindas do reino, como o nascimento de um príncipe, casamentos ou mesmo pela morte de algum soberano. ${ }^{47}$ As contratações executadas pelas câmaras davam-se em praça pública e ganhava o arremate o regente cujo conjunto oferecesse o melhor preço.

Como já foi observado, as irmandades eram espaços igualmente privilegiados para o emprego dos serviços dos músicos pardos e mulatos. As contratações nesse âmbito se davam de forma mais particular do que nas contratações da câmara. Isto é, normalmente o músico/mestre contratado era irmão da irmandade ou já havia criado vínculos profissionais com as associações religiosas. ${ }^{48}$ É interessante pensarmos no impacto que essas festas exerciam sobre a população mineira - e colonial - visto que era o momento máximo

\footnotetext{
${ }^{45}$ LEONI, Aldo Luiz. Os que vivem da arte da música..., p. 48-59.

${ }^{46}$ LEONI, Aldo Luiz. Idem, p. 12.

${ }^{47}$ LANGE, Francisco Curt. La música en Vila Rica..., p. 26.

${ }^{48}$ LEONI, Aldo Luiz. Idem, p. 49.
} 
da exteriorização de suas devoções, bem como um ambiente para o encontro de todos os grupos sociais, inclusive as elites. Se considerarmos que a partir de meados do século XVIII as músicas tocadas nesses eventos eram criadas e executadas essencialmente por pardos, poderemos chegar a ter um vislumbre do que foi a experiência social desses indivíduos peculiares. Ora, ao transitarem no mundo dos brancos, seja criando músicas para executarem-nas em suas festas devocionais ou como professores de música renomados, estabeleciam relações de poder e poderiam galgar recursos simbólicos e econômicos. Nesta direção, a trajetória do pardo Francisco Gomes da Rocha (1754-1808), analisada por Aldo Luiz Leoni, tem muito a nos dizer sobre as estratégias destes sujeitos. São conhecidas suas atividades como músico nas festividades do Santíssimo Sacramento (1777-1784), Nossa Senhora do Pilar (1781-1803) e Mercês de Cima (1777-1784). Foi confrade nas irmandades de São Francisco de Paula (1782-1808), São José dos Homens Pardos e da Nossa Senhora da Boa Morte (1766-1808), ocupando nelas por algumas vezes o importantíssimo cargo de juiz. Também exerceu as funções de ajudante de um dos terços dos homens pardos, este um dos poucos postos remunerados das tropas auxiliares e que exigia nível elevado de capacitação técnica de seu ocupante, e posteriormente o de timbaleiro da cavalaria regular. ${ }^{49}$ Têm-se referências mais precisas sobre suas atividades em função de sua petição para reforma. Em resposta, o governador Bernardo José de Lorena acentuou suas atividades nos toques militares dos timbales e como tocador de fagote nas cerimônias cívicas. Por sua vez, o sargento-mor da companhia de cavalaria da qual Francisco fizera parte disse do peticionário que este tinha "a geral estimação das primeiras pessoas daquela capitania, além disso, é um perfeito professor de música, tanto em composição como em execução, tocando ou cantando". O final dessa história é um tanto quando decepcionante, pois Francisco morreu em 1808, sem

${ }^{49}$ LEONI, Aldo Luiz. Os que vivem da arte da música..., p. 73. 
receber a graça que lhe fora concedida. ${ }^{50}$ No entanto, os vestígios de sua vida e atuação demonstram que este homem era estimado por seus superiores e pode-se dizer que se destacava mesmo dos outros pardos que porventura não exercessem funções tão caras e respeitadas naquela sociedade, como era a da música.

O caso de Francisco Gomes da Rocha não constitui exceção, mas revela traços que se repetiram em várias outras trajetórias. Assim, podemos nos remeter à vida de Florêncio José Ferreira Coutinho (1751-1819) que, como Francisco, era músico e militar e ocupou os cargos de trombeta e timbaleiro de um regimento de cavalaria paga. Um momento importante da atuação desse sujeito encontra-se registrado na petição, junto ao Conselho Ultramarino, visando à confirmação da criação da irmandade de Santa Cecília ${ }^{51}$, a qual que seria composta por músicos e músicos militares em Vila Rica no ano de 1812. Florêncio consta como cabeça da petição, donde se infere sua condição de destaque perante os demais músicos e militares de cor. ${ }^{52}$ As histórias de Francisco Gomes da Rocha e Florêncio Coutinho sugerem-nos - mesmo sabendo que podemos incorrer em generalizações - que a atividade musical no território

${ }^{50}$ Apud. Leoni, Aldo Luiz. Idem, p. 73-74.

${ }^{51}$ Destaca-se aqui o fato de que sob a invocação de Santa Cecília unia-se em uma mesma corporação tanto o ofício comum como a devoção religiosa, pois esta santa era justamente a padroeira dos músicos. Esta era uma situação peculiar na medida em que africanos e crioulos privilegiavam a devoção a santos que, de alguma forma, remetiam a um passado africano que melhor conviesse às identidades dos grupos étnicos (TINHORÃO, 1997, p. 136-138; MATTOS, 2006, p. 138) - a despeito da vinculação do padroeiro a algum ofício. No caso em particular dos irmãos músicos, possivelmente a idéia tenha sido, além de apresentarem-se fortalecidos perante o mercado de trabalho como corporação, a de afastarem-se daquele passado africano e dos estigmas a ele vinculados, adotando no lugar uma outra referência, a da profissão que lhes possibilitaria mais chances de ascensão social.

52 LANGE, Francisco Curt. Algumas novidades em torno a atividade musical erudita no período colonial de Minas Gerais. Latin American Music Review, v. 4, n. 2, Autumn - Winter, 1983. p. 5-6; LEONI, Aldo Luiz. Os que vivem da arte da música..., p. 75-76. 
mineiro não constituía a única fonte de ganhos materiais e simbólicos dos músicos em questão, mas era aliada a outras atividades, como funções nos corpos militares e nas irmandades. Por certo, cada um desses âmbitos possibilitava aos homens de cor oportunidades de constituírem representações sociais mais elevadas, haja vista, por exemplo, o caso desses pardos que serviam em tropas destinadas essencialmente aos brancos, como era o caso da cavalaria. Dessa forma, o campo musical pode ser entendido, assim como as irmandades e os corpos militares, como um espaço que poderia criar as condições para a modificação de status, tanto ao nível do grupo de homens de cor como da sociedade em geral.

Comparativamente a Minas Gerais, a situação dos músicos de cor na capitania de São Paulo foi bem diversa tanto no século XVIII quanto nas duas primeiras décadas do seguinte. Existe atualmente um esforço para relativizar uma determinada visão sobre a capitania de São Vicente, posteriormente São Paulo, a qual caracteriza esse espaço como rudimentar materialmente e com economia pobre e estagnada até pelo menos a década de $1760 .^{53}$ Todavia, sabe-se que a capitania em questão, em comparação com áreas dinâmicas como Rio de Janeiro, Minas Gerais, Pernambuco e Bahia, era mais modesta em termos de riqueza. Com efeito, ali a transição entre as formas de trabalho assentadas em braço indígena para àquela baseada em escravos africanos ganhou corpo somente no início do século XVIII, durando pelo menos meio século. ${ }^{54}$ Ademais, a presença de escravos africanos e homens de cor livres na capitania em questão teve evidência sobretudo a partir das duas últimas décadas do setecentos e

${ }^{53}$ Essa historiografia revisionista pode ser exemplificada pelas obras de BLAJ, Ilana. A trama das tensões: o processo de mercantilização de São Paulo colonial (1681-1721). São Paulo: Humanitas/FFLCH/USP, 2002 e BORREGO, Maria Aparecida de Menezes. A teia mercantil: negócios e poderes em São Paulo colonial (1711-1765). Tese (doutorado em história) - Faculdade de Filosofia, Letras e Ciências Humanas da Universidade de São Paulo, 2006.

${ }^{54}$ MONTEIRO, John Manuel. Negros da terra: índios e bandeirantes nas origens de São Paulo. São Paulo: Companhia das Letras, 1994. p. 220-225. 
início do século XIX, acompanhando o incremento do cultivo e beneficiamento da cana-de-açúcar. Em 1772, o número de cativos chegava a 28.542 pessoas, representando cerca de $24,4 \%$ de uma população estimada em 116.975 indivíduos. Esta camada social cresceu rapidamente entre 1777 e 1829, atingindo o número de 75 mil pessoas. Paralelamente, desenvolveu-se uma classe formada por homens livres de cor, que em 1772 chegava a 22.459 pessoas, ou $19,2 \%$ da população total de São Paulo. Esta população de homens de cor livres mais que dobrou em cinqüenta anos, uma vez que em 1822 era composta por aproximadamente 52.850 homens e mulheres. ${ }^{55}$ Não obstante apresentarem crescimento contínuo, as camadas sociais formadas por negros livres e escravos de São Paulo, numericamente, em momento algum se aproximaram das existentes em Minas Gerais, pois lá, em 1814, apenas os indivíduos livres de cor eram em número de 143.080 pessoas. $^{56}$

Distinto também foi o impacto social das camadas de negros livres nas duas regiões aqui consideradas. Por exemplo, ao contrário de Minas Gerais, onde por boa parte do século XVIII milhares de pardos e pretos livres formavam vários terços militares de auxiliares ou ordenanças, em São Paulo a existência de uma corporação semelhante, e, por sinal, a única destinada exclusivamente a pardos forros, se deu apenas em 1797, com a criação do regimento miliciano dos Úteis. ${ }^{57}$ De modo análogo, ao grande número de irmandades negras presentes em toda a capitania de Minas Gerais, contrasta a existência de apenas três irmandades organizadas por negros na

\footnotetext{
55 ALDEN, Dauril. The population of Brazil in the late eighteenth century: A preliminary study. The hispanic American historical review, v. 43, n. 2, maio/1963. p. 196; LUNA, F. V.; KLEIN, H. S. Evolução da sociedade e economia escravista de São Paulo, de 1750 a 1850. São Paulo: EDUSP, 2006. p. 167.

${ }^{56}$ KLEIN, Herbert S. Os homens livres de cor..., p. 8.

57 Cf: "Para o Conselho Ultramarino sobre participar estarem regulados os regimentos de milícias desta capitania”. Documentos interessantes para a história e costumes de São Paulo, v. XXIX, p. 35-36. São Paulo, 20 de novembro de 1797.
} 
cidade de São Paulo durante o período considerado ${ }^{58}$, embora houvesse algumas confrarias negras a mais, espalhadas pelas principais vilas da capitania. Diante destes dados, sugere-se que a sociedade paulista era consideravelmente mais "fechada" a seus negros livres em relação à mineira. Ou seja, grosso modo São Paulo contava com pouquíssimas instituições próprias aos homens de cor e tampouco se levava a efeito na capitania uma política de inclusão destes sujeitos às corporações dos brancos.

Os caminhos da música erudita em São Paulo acompanharam a trajetória econômica e social daquele espaço durante todo o século XVIII. Já se indicou aqui a posição de Régis Duprat, especialista na obra do português André da Silva Gomes, que por sua vez atuou na Sé de São Paulo como mestre-de-capela ao longo do último quartel do setecentos: para o musicólogo, até a chegada de Silva Gomes à capitania, sua vida musical provavelmente tenha sido "modesta e inexpressiva", marcada pela "precariedade". 59 Em parte, a precariedade a que Duprat se refere está relacionada com a falta de interesse e, principalmente, às dificuldades de financiamento aos músicos. Mesmo os mestres-de-capela, mais bem pagos que outros musicistas, careciam complementar o ordenado com outras fontes de renda, algo raríssimo em Minas Gerais. ${ }^{60}$ Conseqüentemente, divididos entre a arte da música e outros diversos ofícios, as composições feitas em São Paulo tendiam a perder em qualidade.

Se nas Minas Gerais os músicos de cor que constituíam uma elite entre os negros "circulavam livremente e se apresentavam também nos templos cujas irmandades e ordens terceiras só admitiam

${ }^{58}$ MATTOS, Regiane Augusto de. De cassange, mina, benguela a gentio da Guiné. Grupos étnicos e formação de identidades africanas na cidade de São Paulo (18001850). Dissertação (mestrado em história) -Faculdade de Filosofia, Letras e Ciências Humanas da Universidade de São Paulo, 2006. p. 141-145.

59 DUPRAT, Régis. Música na Matriz da Sé de São Paulo colonial. Anuario Interamericano de Investigacion Musical, v. 11, 1975. p. 9.

${ }^{60}$ LANGE, Francisco Curt. Os irmãos músicos..., p. 123; DUPRAT, Régis. Idem, p. 35-36. 
brancos”, e se, como afirma Lange com algum exagero, ali inexistia a possibilidade de uma discriminação racial ${ }^{61}$, o mesmo não se pode dizer do que se passava na vizinha capitania de São Paulo. Por ocasião do nascimento do infante Pedro, futuro imperador do Brasil, a Câmara da vila de Jacareí organizara um festejo, em fevereiro de 1799, "com missa cantada e senhor exposto". Tratava-se de uma solenidade das mais importantes, sem dúvida, pois o cerimonial todo conectava os habitantes de Jacareí simultaneamente a família real portuguesa e a Deus. Outrossim, através dela revelar-se-iam os signos de poder e prestígio associados às elites locais. Uma carta enviada pelo capitão-general e governador de São Paulo diretamente à Câmara da vila em questão, no entanto, indica que os desentendimentos entre camaristas e o vigário deram contornos inesperados à missa solene: é que "em razão de ele [, o vigário,] repugnar que um mulato - autor de várias desordens - cantasse na dita função, não só não quiseram" os camaristas "ir assistir a ela em corpo de Câmara; mas procuraram impedir que ele [, o vigário,] a fizesse, como de fato fez, à sua custa”. Finalmente, alguns meses após o pároco representar ao governador Antonio Manoel de Mello Castro e Mendonça "a violência" feita por seus opositores nesta ocasião, "mandando-o chamar à Casa da Câmara" no mesmo dia da festa, os patrocinadores do músico mulato - cujo nome infelizmente não consta das cartas - foram repreendidos por faltarem "o respeito devido aos ministros do altar (...) por uma coisa tão pequena”. ${ }^{62}$

Em 1774, porém, uma outra querela na qual estava envolvido diretamente um músico mulato não foi considerada "pequena" pelo então governador D. Luiz Antonio de Souza. Prova disso é sua carta consultiva enviada ao Conselho Ultramarino. Nela informava a Martinho de Mello e Castro acerca das divergências entre as altas

\footnotetext{
${ }^{61}$ LANGE, Francisco Curt. A música barroca..., p. 129.

${ }^{62}$ Cf. "Para a Câmara da vila de Jacareí". Documentos interessantes para a história e costumes de São Paulo (D.I.), v. LXXXVII, p. 150. São Paulo, 26 de fevereiro de 1799; "Para a Câmara da vila de Jacareí". D.I., v. LXXXVII, p. 163-164. São Paulo, 15 de junho de 1799.
} 
autoridades eclesiásticas e o restante da população da cidade de São Paulo no que diz respeito aos "músicos e aqueles que hão de cantar nas festividades". Dada a riqueza de detalhes contida na epístola, segue transcrita em sua quase totalidade:

Quando cheguei a esta Capitania, era mestre-da-capela o padre Mathias Alves Torres, de idade de setenta anos, e conforme a ela era também a música e a solfa ${ }^{63}$. Com a minha chegada acudiu da Bahia Antonio Manso e seus irmãos, todos professores de músicas, providos das melhores solfas de bom gosto do tempo presente. Ensinaram logo vários tiples $^{64}$, e compuseram um coro que se podia ouvir. A este Antonio Manso proveu o vigário capitular, o reverendo doutor Manoel José Vaz, em mestre-da-capela por despacho de 23 de fevereiro de 1768. Mudando depois o governo, e sendo o vigário capitular o doutor Matheus Lourenço de Carvalho, proveu em um seu afilhado, Antonio de Oliveira, e tornando a mudar o governo, e sendo governador do bispado o reverendo cônego Antonio de Toledo Lara, tornou a prover ao dito Antonio Manso por despacho de 22 de dezembro de 1773. E este era o mestre-da-capela ao tempo que chegou o excelentíssimo bispo a este bispado.

Porém como as festividades desta terra não dão os lucros suficientes para se poder conservar um bom coro de música, qual é a do dito Manso, lhe ajustei eu a direção da Casa da Ópera, que já aqui havia. Cuja Casa não representa formalmente todas as semanas como em outras partes, mas sim quando sucede, e em dias maiores, porque também não rende o lucro suficiente para se conservar regularmente e à parte. Porém com uma e outra coisa era o que bastava para o dito Manso ir vivendo, e se fazerem as coisas bem.

Como o excelentíssimo bispo trouxe consigo mestre-da-capela, fez proibir em todas as Igrejas que se não admitisse o dito Manso com o motivo de que era operário e mulato, e que a sua música era de violinos; sendo que o dito Manso nem consta que seja mulato, nem o parece nas

${ }^{63}$ Solfa: “As notas da música”. In: BLUTEAU, Raphael. Vocabulario portuguez \& latino: aulico, anatomico, architectonico ... Coimbra: Collegio das Artes da Companhia de Jesus, 1712 - 1728. 8 v. Disponível em: http://www.brasiliana.usp.br/ e http://www.ieb.usp.br/.

${ }^{64}$ Tiple: "Para bem se houvera de dizer Triple, porque das três vozes, que fazem boa consonância na Música Baxo, Tenor, e Tiple, esta é a terceira, e a mais alta, que é a razão porque lhe chamam os franceses Le superius, e os Italianos Soprano (...)”. In: Rafael Bluteau. Op.cit. 
cores, nem ainda que o fosse, se lhe devia imputar este defeito em virtude das novíssimas leis de sua majestade. Nem o ser operário lhe pode servir de defeito, porque isto mais é um divertimento que eu conservo quase todo à custa da minha bolsa, do que uma Casa de Ópera formal, e fomentada pelo povo.

Porém o fim para que se acumulam estes defeitos, é por que como o excelentíssimo bispo só quer que cante o seu mestre-da-capela, busca estes meios para que só ele as tenha, e seja chamado. E não sucede assim porque costumado o povo a ouvir a música do Manso que lhe é mais agradável do que a música do mestre-da-capela da Sé, que é destituída de instrumentos, acontece que faltando na música da Sé aquelas vozes italianas, e aquele estilo elevado que na Patriarcal, e em Roma faz a admiração de todos. E sendo substituídos por rapazes da terra sem voz, sem estilo, sem conhecimento de solfa, e sem ajuda dos instrumentos, fica uma tal música que não se pode ouvir. ${ }^{65}$

Antonio Manso da Mota, como se viu, deixou a Bahia com seus familiares para atender às necessidades da Sé de São Paulo após a chegada do morgado de Mateus na cidade, em 1766. Em verdade, Antonio Manso era mineiro, de Sabará, posteriormente é que seguiu com sua parentela para a Bahia, residindo provavelmente na então capital da América portuguesa, Salvador. Nota-se, pois, a grande mobilidade espacial que este como tantos outros músicos experimentaram, fruto, possivelmente, de suas habilidades na arte da música. Atualizado "nas melhores solfas de bom gosto" e cumprindo com seus deveres no ensino e prática de música erudita, logo Manso conquistou o posto máximo de sua atividade na capitania, o de mestre-de-capela da Sé. Entretanto, além da necessidade de submeterse a outro ofício, para o qual Manso igualmente ocupava a posição mais elevada - a de diretor da Casa da Ópera -, por duas vezes foi-lhe

${ }^{65}$ Cf. "Relação, feita pelo oficial-maior da Secretaria de São Paulo, Manuel Teixeira da Silva, contendo seis ofícios, do governador e capitão-general da capitania de São Paulo, D. Luís António de Sousa, para o ministro e secretário de Estado da Marinha e Domínios Ultramarinos, Martinho de Melo e Castro, referentes ao estado eclesiástico". Arquivo Histórico Ultramarino - São Paulo, Coleção Alfredo Mendes Gouveia (1618-1823), cx. 29, doc. 2666. São Paulo, 18 de junho de 1774. 
retirado o mestrado da Sé. Vale lembrar a este respeito que cabia aos bispos prover tais cargos, ao passo que às demais autoridades políticas restava relatar eventuais desordens ao Conselho Ultramarino, como o fez D. Luiz Antonio em 1774.

Nos dois casos examinados, por sinal, percebe-se que a disputa por cargos, postos e posições entre os músicos na capitania de São Paulo, fossem eles mestres-de-capela ou não, se fazia mediante envolvimento de diversos segmentos da sociedade. As atividades musicais não exigiam apenas a anuência de seus financiadores. Nestas disputas por poder os concorrentes surgiam associados e contando com os recursos e a influência de determinados grupos políticos, e isto é um indicativo de que extrapolavam, e muito, a esfera da habilidade e gosto musical. ${ }^{66}$ Ademais, como é comum em disputas desta natureza, continuamente recorria-se a estigmatização do adversário. ${ }^{67}$ Note-se, no caso da contenda entre o vigário e os camaristas de Jacareí, que o nome do músico mulato sequer foi mencionado. Já sua cor sim, foi indispensável na argüição tanto do pároco quanto do governador. Antonio Manso, de igual modo, foi taxado de mulato e oficial mecânico, desqualificações estas que D. Luiz Antonio de Souza fez questão de negar. ${ }^{68}$ Aliás, invocando os

66 Não se quer aqui, evidentemente, relegar a um segundo plano o papel desempenhado pelas transformações gerais do gosto musical, marcada pela transição progressiva da influência do ambiente religioso para o laico, da hegemonia do emprego das vozes para a intercalação de vozes e instrumentos aspectos brilhantemente destacados por POLASTRE, Cláudia Aparecida. A música na cidade de São Paulo (1765-1822). Tese (doutorado em História) - Faculdade de Filosofia, Letras e Ciências Humanas da Universidade de São Paulo, 2008. Antes, procura-se compreender o fenômeno ocorrido em São Paulo a partir de outros elementos importantes freqüentemente deixados de lado.

${ }^{67}$ ELIAS, Norbert; SCOTSON, John. Os estabelecidos e os outsiders...

${ }^{68}$ Embora o governador e capitão-general D. Luiz Antonio de Souza rechaçasse as atribuições pejorativas a Antonio Manso, como a cor mulata e o exercício de ofícios mecânicos, na Lista Geral de todos os povos, de 1775, Manso foi descrito como um operário de 44 anos de idade. Por outro lado, não há quaisquer referências à ascendência africana. $C f$. "Lista geral de todos os povos - homens, mulheres, auxiliares de pé e de cavalo - e suas idades, do distrito desta cidade de São Paulo 
termos do alvará de 17 de janeiro de $1773^{69}$, o governador e capitãogeneral entendia que a cor não era mais impedimento para o acesso ao posto em questão. Além disso, a defesa de Manso baseava-se em boa medida nos excelentes serviços por ele prestados como também em sua habilidade e atualização musical que muito agradavam a população. Fosse como fosse, o certo é que a estigmatização obtinha algum grau significativo de eficácia em São Paulo, na primeira metade do século XVIII. Ali, ao contrário das Minas Gerais, onde "a música estava em mãos dos mulatos que dominavam sua arte, executando-a com perfeição”, o acesso aos principais cargos no campo da música constantemente era obstado aos seus homens de cor, menos por incompetência destes, mais pela condição de outsiders, pelo grande diferencial de poder entre negros e brancos na capitania de São Paulo. ${ }^{70}$

Algo cambiaria a partir do século XIX, pois o esplendor das Minas Gerais de outrora havia entrado em decadência, conjuntamente com a estagnação da atividade mineradora. Nesse ínterim, muitos músicos, não usufruindo das mesmas oportunidades do período áureo das Minas Gerais, partiram em direção à corte no Rio de Janeiro ou abandonaram suas antigas funções, o que, por certo, contribuiu para um decréscimo da produção musical naquela região. ${ }^{71}$ Em São Paulo,

pertencente ao capitão de ordenança dela”. Revista do Instituto Histórico e Geographico de São Paulo, v. XXXIV, 1938, p. 585.

${ }^{69}$ Este alvará previa que todos aqueles cativos cujas bisavós fossem escravas seriam libertados. Além disso, determinava-se também que os libertos teriam acesso a todos os cargos e honras da monarquia, abolindo-se, dessa forma, a nota distintiva de libertos. Para além da interpretação deslocada geograficamente do governador, visto que este alvará só se aplicava aos libertos do reino, pode-se pensar que sua argumentação se pautava justamente na abolição do impedimento dos homens de cor libertos terem acesso aos cargos oficiais. Cf. Alvará com força de Lei de 16 de janeiro de 1773. In: LARA, Silvia (Org.). "Legislação sobre escravos africanos na América portuguesa”. In: José Andrés-Gallego (Dir. e Coord.). Nuevas aportaciones a la historia jurídica de Iberoamérica. Madrid: Fundación Histórica Tavera, 2000. p. 359. (Cd-rom).

${ }^{70}$ LANGE, Francisco Curt. A música barroca..., p. 129.

${ }^{71}$ LANGE, Francisco Curt. Os irmãos músicos da Irmandade de São José..., p. 3-4. 
por outro lado, muito timidamente os músicos de cor conquistaram um espaço de destaque, e isto geralmente implicava assim a vinculação na corporação militar própria aos pardos como o estabelecimento de relações pessoais com as autoridades. Porém, somente em 1819 é que um pardo tornou a ocupar o posto de mestrede-capela da Sé. Evidentemente, Francisco de Paula Leite Prestes traçara até ali um largo caminho: ingressou no regimento miliciano dos Úteis, exclusivo aos homens pardos, em 1810, e lá ocupou o prestigiado posto de capitão da $1{ }^{\text {a }}$ Companhia de Fuzileiros da cidade de São Paulo. ${ }^{72}$ De outra parte, em 1815, Manoel José Gomes, cujo pai, pardo, era soldado no regimento dos Úteis, tornou-se mestre-decapela na vila de São Carlos, atual Campinas. Manoel foi pai e mestre do célebre compositor paulista Antônio Carlos Gomes. ${ }^{73}$ Além disso, segundo o musicólogo Fernando Binder, como reconhecimento à fidelidade e aceitação dos novos projetos políticos por parte dos milicianos pardos, em 1825 o imperador D. Pedro I agraciou o 3. ${ }^{\circ}$ regimento de milícias de São Paulo, anteriormente denominado "dos Úteis”, com uma composição, o Hino. ${ }^{74}$

Como se vê, apenas com as transformações econômicas e demográficas pelas quais passou São Paulo desde fins do século XVIII, sobretudo àquelas relacionadas ao tráfico de escravos e ao contínuo processo de alforrias, é que houve expressiva atuação de homens de cor naquela sociedade. Os músicos de cor só a partir de então conquistaram um espaço institucional relativamente estável, intercalando cotidianamente o ensino de música erudita às

${ }^{72}$ Cf. "Livro mestre do regimento de infantaria miliciana dos Úteis". Arquivo Público do Estado de São Paulo, ord. 446, p. 97.

${ }^{73}$ DIAS, Vivian Lis Ferreira Nogueira. Um resgate do patrimônio musical paulista: transcrições musicológicas e considerações analíticas de três Missas de Manoel José Gomes, mestre-de-capela em Campinas. Tese (doutorado em música) Instituto de Artes da UNICAMP, 2008. p. 3.

${ }^{74}$ BINDER, Fernando Pereira. Bandas Militares no Brasil: difusão e organização entre 1808-1889. v. I. Dissertação (mestrado em Música) - Instituto de Artes da Universidade Estadual Paulista, 2006. p. 32. 
apresentações teatrais, em missas e nos exercícios militares. Ainda assim, não havia paralelo para com a atividade artística dos mulatos e pardos mineiros do século XVIII, que tanto, e até hoje, fascina historiadores, musicólogos e quem quer que aprecie a arte da música.

\section{Considerações finais}

O estudo sobre as possibilidades de ascensão social de músicos pardos e mulatos durante a segunda metade do século XVIII e as duas primeiras décadas do XIX, bem como o olhar comparativo entre as atuações de tais sujeitos nas capitanias de Minas Gerais e São Paulo, nos permitiu observar algumas questões importantes sobre suas experiências sociais. Em primeiro lugar destacamos a diferenciação desses músicos em relação aos outros homens de cor, justamente por exercerem a arte musical, tão apreciada por todas as camadas sociais, em especial pelas elites, e ao mesmo tempo imprescindível nas várias ocasiões litúrgicas ou profanas. Também o domínio da leitura e escrita certamente contribuiu para acentuar essa distinção, ainda mais num período no qual predominava o analfabetismo. O talento musical permitiu que pardos e mulatos transitassem entre seu mundo social - marcado pelas limitações atribuídas à cor - e o mundo dos brancos. Como professores de música, por exemplo, seus serviços eram contratados por membros das elites. Este contato privado com freqüência refletia positivamente aos músicos na esfera pública, auxiliando-os fosse nas disputas por cargos em que se envolviam, fosse nos processos de arrematação do serviço musical das festas. Nas cerimônias públicas eram responsáveis pela boa condução do ato litúrgico, já que sem música este ficaria incompleto. Nestas ocasiões esses homens figuravam como elementos destacados no corpo social. Chama-se atenção, ademais, para a atuação de homens de cor como mestres-de-capela. Estes exerciam um papel central na organização e gerência da atividade musical, subordinando os demais músicos, inclusive brancos. Outro aspecto a ser ressaltado é vinculação desses músicos 
às irmandades e corpos militares, onde os mais hábeis e influentes, como os mestres mineiros, geralmente ocupavam posições de destaque. Nas irmandades exerciam as principais funções administrativas, como a de juiz, já na esfera militar alcançavam cargos de prestígio no oficialato. Com efeito, a partir destas corporações religiosas e militares podiam exteriorizar signos de prestígio e poder, além de ocasionalmente serem admitidos em instituições exclusivas a brancos, como as ordens terceiras e companhias militares profissionais e de cavalaria.

As máculas associadas tanto à cor quanto ao exercício de ofícios mecânicos atribuídas a estes indivíduos parecem ter funcionado como um rígido a priori sustentado pelas autoridades e de certa forma reconhecido por parte dos músicos de cor, mas que na prática podia tornar-se altamente flexível de acordo com as diversas configurações sociais existentes na América portuguesa ao longo do século XVIII e início do XIX. Resulta daí, pois, a gritante diferença entre os padrões de inserção de pardos e mulatos nos cargos de maior prestígio no tocante às manifestações de música erudita nas capitanias de Minas Gerais e São Paulo. Os músicos de cor jogavam individual e coletivamente com as possibilidades engendradas em cada realidade. Seus movimentos certamente contribuíram para a reprodução e transformação assim da música erudita nos trópicos como das oportunidades a sujeitos galgarem obstáculos rumo a um status social que os afastasse cada vez mais das marcas do cativeiro.

\section{BIBLIOGRAFIA}

ALDEN, Dauril. The population of Brazil in the late eighteenth century: A preliminary study. The hispanic American historical review, v. 43, n. 2, maio/1963.

BERNARDES, Ricardo. José Maurício Nunes Garcia e a Real Capela de D. João VI no Rio de Janeiro. Revista Textos do Brasil, n. 12, s./d. Disponível em: http://www.mre.gov.br/dc/textos/revista12-mat5.pdf . 
BINDER, Fernando Pereira. Bandas Militares no Brasil: difusão e organização entre 1808-1889. v. I. Dissertação (mestrado em Música) - Instituto de Artes da Universidade Estadual Paulista, 2006. BORREGO, Maria Aparecida de Menezes. A teia mercantil: negócios e poderes em São Paulo colonial (1711-1765). Tese (doutorado em história) - Faculdade de Filosofia, Letras e Ciências Humanas da Universidade de São Paulo, 2006.

CARDOSO, Lino de Almeida. O som e o soberano: uma história da depressão musical carioca pós-Abdicação (1831-1843) e de seus antecedentes. Tese (doutorado em História) - Faculdade de Filosofia, Letras e Ciências Humanas da Universidade de São Paulo, 2006.

CARNEIRO, Maria Tucci. Preconceito racial: Portugal e Brasilcolônia. São Paulo: Brasiliense, 1988.

CASTAGNA, Paulo. A produção religiosa nordestina e paulista no período colonial e imperial. In: . Apostila do curso História da Música Brasileira, Instituto de Artes da UNESP, 2004. Disponível em:

http://www.ia.unesp.br/docentes/castagna/hmb/HMB_2004_apostila0 7.pdf .

CASTAGNA, Paulo. Avanços e perspectivas na musicologia histórica brasileira. Revista do Conservatório de Música da UFPel. Pelotas, n. 1, 2008.

DIAS, Vivian Lis Ferreira Nogueira. Um resgate do patrimônio musical paulista: transcrições musicológicas e considerações analíticas de três Missas de Manoel José Gomes, mestre-de-capela em Campinas. Tese (doutorado em música) - Instituto de Artes da UNICAMP, 2008.

DUPRAT, Régis. Música na Matriz da Sé de São Paulo colonial. Anuario Interamericano de Investigacion Musical, v. 11, 1975.

ELIAS, Norbert. Introdução. Ensaio teórico sobre as relações estabelecidos-outsiders. ELIAS, Norbert; SCOTSON, John. Os estabelecidos e os outsiders. Trad. Vera Ribeiro. Rio de Janeiro: Jorge Zahar Editor, 2000. 
ELIAS, Norbert. Mozart, sociologia de um gênio. Rio de Janeiro: Jorge Zahar Ed., 1995.

FERREIRA, Roberto Guedes. Sociedade escravista e mudança de cor. Porto Feliz, São Paulo, século XIX. In: FRAGOSO, João [et al.] (Org.). Nas rotas do império: eixos mercantis, tráfico e relações sociais no mundo português. Vitória/Lisboa: EDUFES/IICTP, v.1, 2006.

HESPANHA, António Manuel. A mobilidade social na sociedade de Antigo Regime. Tempo, v. 11, n. 21, 2006.

HESPANHA, António Manuel. Às vésperas do Leviathan: instituições e poder político, Portugal - séc. XVII. Coimbra, Almedina, 1994.

KLEIN, Herbert S. Os homens livres de cor na sociedade escravista brasileira. Dados - Revista de Ciências Sociais, n. 17, 1978.

KLEIN, Herbert $S$. The colored freemen in brazilian slavery society. Journal of Social History, v. 3, n. 1, 1969.

LANGE, Francisco Curt. A música barroca. In: HOLANDA, Sérgio Buarque de (Org.). História geral da civilização brasileira, $2^{\mathrm{a}}$ ed., t. I, v. II, livro III, São Paulo: Difusão européia do Livro, 1968a.

LANGE, Francisco Curt. Algumas novidades em torno a atividade musical erudita no período colonial de Minas Gerais. Latin American Music Review, v. 4, n. 2, Autumn - Winter, 1983.

LANGE, Francisco Curt. La música en Vila Rica: Minas Gerais século XVIII. Revista Musical Chilena, n.102, 1967.

LANGE, Francisco Curt. Os irmãos músicos da Irmandade de São José dos Homens Pardos, de Vila Rica. Anuario Interamericano de Investigacion Musical, v. 4, 1968b.

LANGE, Francisco Curt. Sobre las dificiles huellas de la musica antigua del Brasil: la "Missa abreviada" del Padre José Maurício Nunes Garcia. Anuario Interamericano de Investigacion Musical, v. 1, 1965.

LARA, Silvia (Org.). "Legislação sobre escravos africanos na América portuguesa”. In: José Andrés-Gallego (Diretor e 
Coordenador). Nuevas aportaciones a la historia jurídica de Iberoamérica. Madrid: Fundación Histórica Tavera, 2000.

LEONI, Aldo Luiz. Os que vivem da arte da música - Vila Rica, século XVIII. Dissertação (mestrado em História) - Instituto de Filosofia e Ciências Humanas da UNICAMP, 2007

LUNA, F. V.; KLEIN, H. S. Evolução da sociedade e economia escravista de São Paulo, de 1750 a 1850. São Paulo: EDUSP, 2006. MARQUESE, Rafael de Bivar. A dinâmica da escravidão no Brasil: resistência, tráfico negreiro e alforrias, séculos XVII a XIX. Novos Estudos. São Paulo, n. 74, 2006.

MATTOS, Regiane Augusto de. De cassange, mina, benguela $a$ gentio da Guiné. Grupos étnicos e formação de identidades africanas na cidade de São Paulo (1800-1850). Dissertação (mestrado em história) - Faculdade de Filosofia, Letras e Ciências Humanas da Universidade de São Paulo, 2006.

MONTEIRO, John Manuel. Negros da terra: índios e bandeirantes nas origens de São Paulo. São Paulo: Companhia das Letras, 1994.

MONTEIRO, Maurício. Música na corte do Brasil: entre Apolo e Dionísio (1808-1821). Textos do Brasil, n. 12, s./d. Disponível em: http://www.mre.gov.br/dc/textos/revista12-mat4.pdf .

OLIVAL, Fernanda. Rigor e interesses: Os estatutos de pureza de sangue em Portugal. Cadernos Sefardistas, n. 4, p. 151-182, 2004.

OLIVEIRA, A. J. M. Suplicando a "dispensa do defeito da cor": clero secular e estratégias de mobilidade social no Bispado do Rio de Janeiro - século XVIII. XIII Encontro de História da Anpuh-Rio, 2008, Seropédica. Anais do XIII Encontro de História da Anpuh-Rio. Rio de Janeiro: Anpuh-Rio, 2008.

ORBINO, N. P.; DUPRAT, R. O estanco da música no Brasil colonial. Anuario Interamericano de Investigacion Musical, v. 4, 1968.

POLASTRE, Cláudia Aparecida. A música na cidade de São Paulo (1765-1822). Tese (doutorado em História) - Faculdade de Filosofia, Letras e Ciências Humanas da Universidade de São Paulo, 2008. 
RUSSELL-WOOD, A. J. R. Escravos e libertos no Brasil colonial. Trad. Maria Beatriz de Medina. Rio de Janeiro: Civilização Brasileira, 2005.

SCHWARTZ, Stuart. Cantos e quilombos numa conspiração de escravos haussás - Bahia, 1814. In: REIS, João José; GOMES, Flávio dos Santos (Orgs.). Liberdade por um fio. História dos quilombos no Brasil. São Paulo: Companhia das Letras, 1998.

SILVA, Luiz Geraldo. Da festa à sedição: sociabilidades, etnia e controle social na América portuguesa (1776-1814). História: Questões \& Debates, Curitiba, n. 30, 1999.

SILVA, Luiz Geraldo. Da festa barroca à intolerância ilustrada. Irmandades católicas e religiosidade negra na América portuguesa (1750-1815). In: SALLES-REESE, V. (Org.). Repensando el pasado, recuperando el futuro. Nuevos aportes interdisciplinares para el estudio de la America Latina colonial. Bogotá: Editorial Pontifícia Universidad Javeriana, 2005.

SOTUYO BLANCO, Pablo. Damião Barbosa de Araújo: de músico militar a mestre de capela. XV Congresso da ANPPOM, 2005, Rio de Janeiro. ANPPOM - Décimo quinto Congresso. Anais. Rio de JaneiroRJ: PPGMUS-UFRJ, 2005.

TINHORÃO, José Ramos. Os Negros em Portugal. Uma presença silenciosa. Lisboa: Editorial Caminho, 1997.

VIANA, Larissa. O idioma da mestiçagem: As irmandades de pardos na América portuguesa. Campinas: Editora da Unicamp, 2007.

VILLALTA, Luiz Carlos. O que se fala e o que se lê: língua, instrução e leitura. In: SOUZA, Laura de Mello e (org). História da Vida Privada no Brasil: Cotidiano e vida privada na América portuguesa. São Paulo: Companhia das Letras, v. 1, 1997, p. 332-385. 